Jurnal Keperawatan Silampari

Volume 4, Nomor 1, Desember 2020

e-ISSN: 2581-1975

p-ISSN: 2597-7482

DOI: https://doi.org/10.31539/jks.v4i1.1474

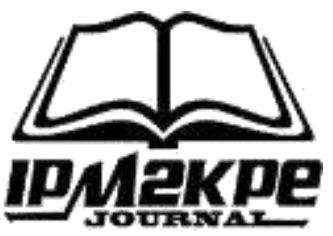

\title{
ANALISIS FAKTOR PENENTU KEPESERTAAN BPJS
}

\author{
Ismatut Thobibah ${ }^{1}$, Ernawaty $^{2,}$ Nyoman Anita Damayanti ${ }^{3}$ \\ Universitas Airlangga ${ }^{1,2,3}$ \\ ismatut.thobibah-2018@fkm.unair.ac.id ${ }^{1}$
}

\begin{abstract}
ABSTRAK
Penelitian ini bertujuan untuk menganalisis hubungan faktor informasi, pengetahuan, dukungan keluarga, dan sikap dengan keputusan menjadi anggota BPJS. Metode penelitian yang digunakan adalah observasional dengan pendekatan cross sectional. Hasil penelitian menunjukkan bahwa, terdapat $69,4 \%$ masyarakat berjenis kelamin perempuan 32,2 \% berusia 36-45 tahun. 53,4 \% berpendidikan SMA. Masyarakat yang menjadi anggota BPJS sebanyak 69,53\%. Terdapat hubungan antara informasi tentang BPJS dengan kepesertaan BPJS (p-value $=0,000$ ), demikian pula dengan dukungan keluarga dan sikap mendukung BPJS, yang ternyata juga berhubungan dengan kepesertaan BPJS (p-value $=0,000$ ). Pengetahuan tentang BPJS tidak berhubungan dengan kepesertaan BPJS ( $p$-value $=0,229$ ). Simpulan, informasi tentang BPJS, dukungan keluarga yang baik dan sikap mendukung terhadap BPJS akan menentukan kepesertaan BPJS, sedangkan pengetahuan tidak berhubungan dengan kepesertaan BPJS.
\end{abstract}

Kata Kunci: Dukungan Keluarga, Informasi, Kepesertaan BPJS, Sikap

\begin{abstract}
This study aims to analyze the relationship between information factors, knowledge, family support, and attitudes to become a member of the BPJS. The research method used was observational with a cross-sectional approach. The results showed that $69.4 \%$ were female, 32.2\% were aged 36-45 years. $53.4 \%$ have a high school education. The people who are members of the BPJS are $69.53 \%$. There is a relationship between information about BPJS and BPJS membership (p-value =0,000) and family support and attitudes to support BPJS, which are also related to BPJS membership ( $p$-value $=0,000)$. Knowledge about BPJS is not related to BPJS membership (p-value $=0.229)$. In conclusion, information about BPJS, good family support, and a supportive attitude towards BPJS will determine BPJS membership, while knowledge is not related to BPJS membership.
\end{abstract}

Keywords: Family Support, Information, BPJS Membership, Attitude

\section{PENDAHULUAN}

Jaminan Kesehatan Nasional (JKN) diselenggarakan berdasarkan Undang-undang Nomor 24 tahun 2011. Mulai tanggal 1 Januari 2014, Badan Penyelenggara Jaminan Sosial (BPJS) Kesehatan menyelenggarakan JKN bagi seluruh rakyat Indonesia baik yang mampu 
maupun tidak mampu. Berdasarkan Peraturan Presiden no 12 tahun 2013 pasal 6 ayat (1), kepesertaan jaminan kesehatan bersifat wajib bagi seluruh penduduk Indonesia. Target Universal Health coverage (UHC) tahun 2019 adalah seluruh Penduduk Indonesia telah terdaftar menjadi anggota BPJS kesehatan. Pencapaian UHC melalui program BPJS diharapkan mampu meningkatkan kesehatan masyarakat. Hal ini akan tercapai apabila seluruh masyarakat telah menjadi anggota BPJS. Berdasarkan Rencana Pembangunan Jangka Menengah Nasional (RPJMN) 2015-2019, persentase penduduk yang menjadi peserta jaminan kesehatan melalui SJSN Bidang Kesehatan dengan target UHC pada tahun 2019 minimal sebesar $95 \%$. Target tersebut ternyata hingga tahun 2020 belum sepenuhnya tercapai (Plianbangchang, 2018).

Salah satu wilayah yang belum mencapai target tersebut adalah Kecamatan Glagah Kabupaten Lamongan. Jumlah penduduk Kecamatan Glagah pada tahun 2018 adalah 34.768 jiwa. Dari jumlah tersebut, sebanyak 29.124 jiwa $(67,46 \%)$ telah menjadi anggota BPJS yang terdiri dari penerima bantuan iuran (PBI), Pekerja Penerima Upah (PPU, meliputi PNS, TNI/POLRI, Pejabat Negara), Pekerja Bukan Penerima Upah (PBPU) dan mandiri. Berdasarkan jumlah tersebut menunjukkan masih ada masyarakat yang belum mendaftar menjadi anggota BPJS. Sehingga target yang seharusnya mencapai $95 \%$ dalam skala kecamatan masih dicapai 67,46 \% (World Health Organisation, 2017).

Banyak faktor yang mempengaruhi seseorang untuk mendaftar atau tidak mendaftar menjadi anggota BPJS. Penelitian sebelumnya yang sudah dilakukan menunjukkan bahwa faktor yang berhubungan dengan keikutsertaan program BPJS Mandiri di Desa Tegalsari Ponorogo adalah pengetahuan, sikap, informasi, penghasilan, dukungan keluarga (Wardani et al., 2017). Penelitian lain yang dilakukan Nadiyah et al., (2017) menunjukkan faktor yang berhubungan keikutsertaan program BPJS Mandiri di Puskesmas Remaja Kota Samarinda adalah pengetahuan, sikap, dukungan keluarga sedangkan faktor kepercayaan tidak berhubungan dengan keikutsertaan program BPJS. Kemudian penelitian lain yang dilakukan oleh Kurniawati \& Rachmayanti (2018) dengan metode Fishbone diagram di Kabupaten Bojonegoro menemukan beberapa faktor yang berpengaruh pada keikutsertaan program BPJS yaitu rendahnya pengetahuan masyarakat, kurangnya sosialisasi, kurangnya media promosi kesehatan, kepala keluarga kurang menyadari pentingnya JKN, dan tingkat pendidikan masyarakat yang rendah. Penelitian lain yang dilakukan oleh Pangestika et al., (2017) menunjukkan hasil yang sedikit berbeda dimana pengetahuan, pendapatan dan jumlah tanggungan keluarga tidak berhubungan dengan kepesertaan BPJS mandiri sedangkan faktor pengeluaran rata-rata perbulan, kemampuan membayar dan dukungan keluarga berhubungan dengan kepesertaan BPJS Mandiri.

Beberapa penelitian yang sudah dilakukan tersebut menunjukkan bahwa faktor perilaku konsumen seperti pengetahuan, sikap, dukungan, informasi serta sosial ekonomi seperti penghasilan merupakan faktor yang sering diteliti. Namun, sejauh ini penelitian, yang sudah ada tersebut belum dapat digeneralisasi untuk seluruh wilayah di Indonesia. Masih terdapat kemungkinan bahwa derajat kepentingan masing-masing faktor penentu kepesertaan BPJS dipengaruhi oleh karakteristik sosial-ekonomi masyarakat setempat. Ini berarti bahwa faktor-faktor penentu kepesertaan BPJS dapat berbeda antara satu daerah dengan daerah yang lain. 


\section{METODE PENELITIAN}

Rancangan penelitian yang digunakan adalah observasional dengan pendekatan cross sectional. Pengambilan data dilakukan pada bulan November 2018 di wilayah kecamatan Glagah Kabupaten Lamongan. Populasi dalam penelitian ini adalah penduduk kecamatan Glagah yang tersebar di 29 desa yang terdiri dari penduduk yang sudah menjadi anggota BPJS dan belum menjadi anggota BPJS. Dengan menggunakan formula Slovin, diperoleh jumlah sampel sebanyak 395 orang. Cara pengambilan sampel menggunakan teknik proportional random sampling.

Uji statistik yang digunakan adalah uji Chi-square. Jenis data pada penelitian ini adalah data kuantitatif yang dikumpulkan dari hasil jawaban kuisioner yang terdiri dari pertanyaan-pertanyaan tentang kepesertaan BPJS, pengetahuan tentang BPJS dan sikap terhadap BPJS. Pada penelitian ini, empat faktor penentu kepesertaan BPJS yang akan dianalisis yaitu: (1) informasi, (2) pengetahuan, (3) dukungan keluarga, dan (4) sikap.

\section{HASIL PENELITIAN}

Tabel. 1

Karakteristik masyarakat Glagah Berdasarkan Jenis Kelamin, Umur dan Tingkat Pendidikan

\begin{tabular}{llcc}
\hline No & \multicolumn{1}{c}{ Karakteristik Responden } & Frekuensi (n) & Persentase (\%) \\
\hline 1 & Jenis Kelamin & & \\
& Laki-laki & 121 & 30,6 \\
& Perempuan & 274 & 69,4 \\
\hline 2 & Umur & & \\
& $<25$ tahun & 34 & 8,6 \\
& 26-35 tahun & 96 & 24,3 \\
& 36-45 tahun & 127 & 32,2 \\
& 46-55 tahun & 106 & 26,8 \\
& 56-65 tahun & 24 & 6,1 \\
& $>$ 65tahun & 8 & 2,0 \\
\hline 3 & Pendidikan terakhir & & \\
& Tidak sekolah & 2 & 5 \\
& SD & 41 & 10,4 \\
& SMP/sederajat & 76 & 19,2 \\
SMA/sederajat & 211 & 53,4 \\
D1/D3/D4 & 16 & 4,1 \\
S1 & 48 & 12,2 \\
S2 & 1 & 3 \\
\hline Total & 395 & 100 \\
\hline
\end{tabular}

Berdasarkan tabel 1 menunjukkan bahwa sebagian besar responden berjenis kelamin perempuan, yaitu sebanyak 272 responden $(69,4 \%)$, mayoritas responden berumur antara 36 - 45 tahun sebanyak 127 responden (32,2 \%), dan mayoritas responden mempunyai pendidikan terakhir tingkat SMA/sederajat sebanyak 211 responden $(53,4 \%)$. 
Tabel. 2

Kepesertaan BPJS

\begin{tabular}{rlcc}
\hline No & Kepesertaan BPJS & Frekuensi (n) & Prosentase (\%) \\
\hline 1 & Anggota BPJS & 275 & 69,6 \\
\hline 2 & Bukan Anggota BPJS & 120 & 30,4 \\
\hline & Total & 375 & 100 \\
\hline
\end{tabular}

Berdasarkan tabel 2 dapat dilihat bahwa 69,6\% atau 275 orang yang sudah menjadi anggota BPJS. Tabel ini menegaskan bahwa jumlah kepesertaan anggota BPJS belum memenuhi target sebesar $95 \%$.

Tabel. 3

Hubungan Informasi dengan Keikutsertaan

Menjadi Anggota BPJS

\begin{tabular}{|c|c|c|c|c|c|c|c|c|}
\hline \multirow{3}{*}{ No } & \multirow{3}{*}{$\begin{array}{c}\text { Informasi tentang } \\
\text { BPJS }\end{array}$} & \multicolumn{4}{|c|}{ Kepesertaan BPJS } & \multirow{2}{*}{\multicolumn{2}{|c|}{ Total }} & \multirow[b]{2}{*}{$P$-value } \\
\hline & & \multicolumn{2}{|c|}{$\begin{array}{c}\text { Bukan } \\
\text { Anggota BPJS }\end{array}$} & \multicolumn{2}{|c|}{$\begin{array}{l}\text { Anggota } \\
\text { BPJS }\end{array}$} & & & \\
\hline & & $\mathrm{n}$ & $\%$ & $\mathrm{n}$ & $\%$ & $\mathrm{~N}$ & $\%$ & \multirow{4}{*}{0,000} \\
\hline 1 & $\begin{array}{ll}\text { Tidak } & \text { Mendapat } \\
\text { Informasi } & \end{array}$ & 14 & 66,7 & 7 & 33,3 & 21 & 100 & \\
\hline 2 & Mendapat Informasi & 106 & 28,3 & 268 & 71,7 & 374 & 100 & \\
\hline & Total & 120 & 30,4 & 275 & 69,6 & 395 & 100 & \\
\hline
\end{tabular}

Berdasarkan tabel 3 menunjukkan bahwa mayoritas masyarakat mendapat informasi tentang BPJS dan telah menjadi anggota BPJS adalah sebanyak 71,7 \%. Berdasarkan uji statistik dengan menggunakan uji chi square, didapatkan hasil bahwa $p$-value $=0,000$ $(<0,05)$. Artinya bahwa terdapat hubungan antara Informasi tentang BPJS dengan keikutsertaan menjadi anggota BPJS.

Tabel 4

Hubungan Pengetahuan tentang

BPJS dengan kepesertaan BPJS

\begin{tabular}{|c|c|c|c|c|c|c|c|c|}
\hline \multirow{3}{*}{ No } & \multirow{3}{*}{$\begin{array}{c}\text { Pengetahuan tentang } \\
\text { BPJS }\end{array}$} & \multicolumn{4}{|c|}{ Kepesertaan BPJS } & \multirow{2}{*}{\multicolumn{2}{|c|}{ Total }} & \multirow{3}{*}{$P$-value } \\
\hline & & \multicolumn{2}{|c|}{$\begin{array}{c}\text { Bukan } \\
\text { Anggota BPJS }\end{array}$} & \multicolumn{2}{|c|}{$\begin{array}{l}\text { Anggota } \\
\text { BPJS }\end{array}$} & & & \\
\hline & & $\mathrm{N}$ & $\%$ & $\mathrm{n}$ & $\%$ & $\mathrm{~N}$ & $\%$ & \\
\hline 1 & Rendah & 4 & 40 & 6 & 60 & 10 & 100 & \multirow{4}{*}{0,229} \\
\hline 2 & Sedang & 83 & 32,8 & 170 & 67,2 & 253 & 100 & \\
\hline 3 & Tinggi & 33 & 25 & 99 & 75 & 132 & 100 & \\
\hline & Total & 120 & 30,4 & 275 & 69,6 & 395 & 100 & \\
\hline
\end{tabular}

Berdasarkan tabel 4 dapat dilihat bahwa bahwa masyarakat dengan pengetahuan BPJS tinggi, tingkat kepesertaannya juga cenderung tinggi, yaitu mencapai $75 \%$. Sedangkan untuk masyarakat dengan pengetahuan rendah terhadap BPJS, tingkat 
kepesertaannya hanya mencapai $60 \%$. Kemudian yang belum menjadi anggota BPJS namun memiliki pengetahuan tinggi sebanyak $25 \%$, sedangkan yang berpengetahuan rendah dan bukan anggota BPJS ada $40 \%$. Hasil uji chi square menunjukknan $p$-value $=$ $0,229(>0,05)$. Dapat disimpulkan bahwa tidak ada hubungan yang signifikan antara pengetahuan dan keanggotaan BPJS. Artinya, hasil penelitain ini menunjukkan bahwa pengetahuan yang didapat tidak cukup untuk dapat mengambil keputusan untuk menjadi peserta BPJS.

Tabel. 5

Hubungan Dukungan Keluarga dengan Kepesertaan BPJS

\begin{tabular}{|c|c|c|c|c|c|c|c|c|}
\hline \multirow{3}{*}{ No } & \multirow{3}{*}{ Dukungan Keluarga } & \multicolumn{4}{|c|}{ Kepesertaan BPJS } & & & \multirow[b]{2}{*}{$P$-value } \\
\hline & & \multicolumn{2}{|c|}{$\begin{array}{c}\text { Bukan } \\
\text { Anggota BPJS }\end{array}$} & \multicolumn{2}{|c|}{$\begin{array}{l}\text { Anggota } \\
\text { BPJS }\end{array}$} & \multicolumn{2}{|c|}{ Total } & \\
\hline & & $\mathrm{n}$ & $\%$ & $\mathrm{n}$ & $\%$ & $\mathrm{~N}$ & $\%$ & \multirow{4}{*}{0,000} \\
\hline 1 & Tidak mendukung & 22 & 95,7 & 1 & 4,3 & 23 & 100 & \\
\hline 2 & Mendukung & 98 & 26,3 & 274 & 73,7 & 372 & 100 & \\
\hline & Total & 120 & 30,4 & 275 & 69,6 & 395 & 100 & \\
\hline
\end{tabular}

Berdasarkan tabel 5 menunjukkan bahwa masyarakat yang mendapat dukungan keluarga akan semakin besar kecenderungan untuk menjadi anggota BPJS, masyarakat dengan dukungan keluarga mempunyai tingkat kepesertaanya mencapai 73,7\% sedangkan masyarakat yang tidak mendapatkan dukungan keluarga tingkat kepesertaannya hanya mencapai 4,3\%. Kemudian yang belum menjadi anggota BPJS namun keluarga mendukung sebanyak 26,3\% sedangkan yang tidak mendapatkan dukungan dan bukan anggota BPJS ada 95,7 \%. Hal ini diperkuat dengan uji chi square yang menghasilkan $p$ value $=0,000(<0,05)$. Dapat disimpulkan bahwa ada hubungan yang signifikan antara dukungan keluarga dan keanggotaan BPJS. Artinya bahwa penting bagi individu mendapatkan dukungan keluarga sebagai penguat untuk ikut serta menjadi anggota BPJS.

Tabel 6

Hubungan Sikap terhadap BPJS dengan Kepesertaan BPJS

\begin{tabular}{|c|c|c|c|c|c|c|c|c|}
\hline \multirow{3}{*}{ No } & \multirow{3}{*}{ Sikap } & \multicolumn{4}{|c|}{ Kepesertaan BPJS } & & & \multirow{3}{*}{ P-value } \\
\hline & & \multicolumn{2}{|c|}{$\begin{array}{c}\text { Bukan } \\
\text { Anggota } \\
\text { BPJS }\end{array}$} & \multicolumn{2}{|c|}{$\begin{array}{l}\text { Anggota } \\
\text { BPJS }\end{array}$} & \multicolumn{2}{|c|}{ Total } & \\
\hline & & $\mathrm{n}$ & $\%$ & $\mathrm{~N}$ & $\%$ & $\mathrm{~N}$ & $\%$ & \\
\hline 1 & $\begin{array}{l}\text { Sangat tidak } \\
\text { mendukung }\end{array}$ & 6 & 46,7 & 7 & 53,8 & 13 & 100 & \multirow{5}{*}{0,000} \\
\hline 2 & Tidak Mendukung & 60 & 44,8 & 74 & 55,2 & 134 & 100 & \\
\hline 3 & Mendukung & 53 & 24,7 & 162 & 75,3 & 215 & 100 & \\
\hline 4 & Sangat mendukung & 1 & 3 & 32 & 97 & 33 & 100 & \\
\hline & Total & 120 & 30,4 & 275 & 69,6 & 395 & 100 & \\
\hline
\end{tabular}


Berdasarkan tabel 6 menunjukkan semakin tinggi tingkat dukungan terhadap BPJS semakin tinggi pula persentase kepesertaan BPJS. Kepesertaan BPJS hanya mencapai $53,8 \%$ pada masyarakat yang sangat tidak mendukung BPJS dan mencapai $97 \%$ pada masyarakat yang sangat mendukung BPJS. Kemudian yang belum menjadi anggota BPJS namun memiliki sikap sangat mendukung sebanyak $3 \%$, dan memiliki sikap yang sangat tidak mendukung ada 46,7 \%. Berdasarkan uji statistik dengan menggunakan uji chi square, didapatkan hasil bahwa $p$-value $=0,000(<0,05)$. Artinya bahwa terdapat hubungan antara sikap masyarakat terhadap BPJS dengan keikutsertaan menjadi anggota BPJS. Hasil ini menunjukkan bahwa sikap merupakan faktor perilaku konsumen yang penting dalam menentukan kepersertaan BPJS.

\section{PEMBAHASAN}

\section{Hubungan Informasi dengan Keikutsertaan Menjadi Anggota BPJS}

Hasil penelitian menunjukkan persentase masyarakat yang menjadi anggota BPJS lebih tinggi pada masyarakat yang mendapatkan informasi tentang BPJS, dan sebaliknya jika kurang mendapatkan informasi maka tidak menjadi anggota BPJS. Dengan kata lain, adanya hubungan yang signifikan informasi tentang BPJS akan menyebabkan seseorang untuk mendaftar menjadi anggota BPJS. Hasil penelitian ini sejalan dengan beberapa hasil penelitian yang menunjukkan bahwa ada hubungan yang signifikan antara informasi yang diperoleh kepala keluarga dengan keikutsertaan dalam jaminan kesehatan nasional (Wardani et al., (2017); Purwaningsih, 2016). Penelitian ini juga sejalan dengan penelitian yang dilakukan oleh Kurniawati \& Rachmayanti (2018) yang menyatakan bahwa informasi merupakan salah satu faktor yang menyebabkan rendahnya kepesertaan BPJS.

Sumber informasi tentang JKN yang didapat masyarakat Desa Glagah mayoritas melalui tenaga kesehatan yang tersebar di seluruh desa dan tokoh masyarakat, sehingga mereka mengetahui secara langsung dan jelas mengenai informasi tersebut. Tenaga kesehatan baik yang bertugas di Puskesmas Glagah maupun di Puskesmas pembantu (Pustu) ataupun Pondok Bersalin Desa (Polindes) dan Pondok Kesehatan Desa (Ponkesdes) semuanya selalu siap dalam memberikan informasi tentang BPJS. Responden pada penelitian ini sebagian besar berusia 36 - 45 tahun, usia ini merupakan usia produktif dimana mereka selalu aktif dalam mencari informasi termasuk informasi tentang BPJS. Selain itu lokasi Desa Glagah yang tidak terlalu jauh dari kota sangat memungkinkan untuk akses internet sehingga masyarakat bisa dengan mudah mengakses internet melalui media online.

\section{Hubungan Pengetahuan tentang BPJS dengan Kepesertaan BPJS}

Hasil penelitian ini menunjukkan tidak ada hubungan yang signifikan pengetahuan dengan tingkat kepesertaan BPJS. Penelitian ini pengetahuan tidak selalu melahirkan keputusan kepesertaan BPJS. Hasil penelitian ini bertentangan dengan penelitian sebelumnya yang dilakukan Hidayat et al., (2019) yang menyatakan bahwa ada hubungan antara pengetahuan dengan keanggotaan JKN. Beberapa penelitian lain juga menunjukkan bahwa ada hubungan pengetahuan dengan keanggotaan JKS (Hikmah et al., 2019; Kurniawati \& Rachmayanti, 2018; Lestari \& Djamaludin, 2017). Penelitian lain juga menunjukkan hasil yang sama, ada hubungan pengetahuan dengan kepesertaan JKN (Nelisma et al., 2019; Purwaningsih, 2016; Wardani et al., 2017). 
Tidak adanya pengaruh pengetahuan dengan keputusan menjadi peserta BPJS, ini dapat dijelaskan bahwa meskipun pengetahuan tentang BPJS tinggi namun masyarakat belum menggunakan BPJS karena merasa belum memerlukan BPJS. Mereka berpendapat bahwa BPJS penting namun dibutuhkan saat sakit. Sedangkan kondisi saat ini sedang dalam keadaan sehat sehingga masih belum untuk menggunakan BPJS. Kemudian beberapa responden yang pengetahuan rendah namun memutuskan menggunakan BPJS bisa jadi karena merupakan ASN atau berada pada perusahaan atau institusi yang sudah menerapkan jaminan kesehatan atau mereka termasuk BPJS PBI (Penerima Bantuan Iuran). Penerima Bantuan Iuran (PBI) merupakan peserta BPJS bagi fakir miskin dan orang tidak mampu sebagaimana diamanatkan UU SJSN dimana iurannya dibayari Pemerintah sebagai peserta program BPJS Kesehatan. Peserta PBI adalah fakir miskin yang ditetapkan oleh Pemerintah dan diatur melalui Peraturan Pemerintah

Hasil penelitian ini sejalan dengan hasil penelitian Pangestika et al., (2017) tidak ada hubungan antara pengetahuan dengan kepesertaan BPJS Kesehatan mandiri pada sektor informal di kota Pekalongan. Pengetahuan tidak selalu identik dengan pendidikan. Individu dengan pendidikan tinggi namun tidak mengupdate informasi melalui buku dan sumber bacaan lain maka pengetahuan tidak meningkat. Sebaliknya meskipun pendidikan tidak tinggi namun individu tersebut terus mengupdate informasinya dari berbagai sumber maka pengetahuannya akan meningkat. Pengetahuan sendiri bisa membuat individu menahan perilakunya akibat pemikiran resiko yang lebih besar dibandingkan mempertimbangkan manfaat yang akan diperoleh.

\section{Hubungan Dukungan Keluarga dengan Kepesertaan BPJS}

Hasil penelitian menunjukkan masyarakat yang mendapat dukungan keluarga akan semakin besar kecenderungan untuk menjadi anggota BPJS, dan sebaliknya jika kurang mendapatkan dukungan keluarga maka tidak menjadi anggota BPJS. Dengan kata lain, ada hubungan yang signifikan dukungan keluarga dengan kepesertaan BPJS. Hasil penelitian ini sejalan dengan hasil penelitian Pangestika et al., (2017) yang menyatakan bahwa ada hubungan antara dukungan keluarga dengan kepesertaan BPJS.

Bentuk dukungan yang diberikan keluarga berupa informasi tentang BPJS kesehatan yaitu cara mendaftar, tempat mendaftar dan besarnya iuran yang harus dibayar serta pentingnya menjadi anggota BPJS kesehatan. Adanya dukungan dari keluarga menunjukkan bahwa keluarga sangat peduli dan memperhatikan kondisi anggota keluarganya sehingga cenderung untuk mendukung keikutsertaan menjadi anggota BPJS. Individu yang mendapatkan dukungan sosial akan merasa bahwa dirinya diperhatikan, dihargai, disayangi sehingga menjadi kekuatan bagi individu.

\section{Hubungan Sikap terhadap BPJS dengan Kepesertaan BPJS}

Hasil penelitian menunjukkan semakin tinggi sikap mendukung BPJS akan semakin besar kecenderungan untuk menjadi anggota BPJS, dan sebaliknya jika semakin rendah sikap mendukung BPJS maka tidak menjadi anggota BPJS. Dengan kata lain, ada hubungan yang signifikan sikap mendukung BPJS dengan kepesertaan BPJS. Hasil penelitian ini sejalan dengan penelitian yang dilakukan oleh Wardani et al., (2017) yang menunjukkan bahwa ada hubungan yang signifikan antara sikap dan kepesertaan JKN. 
Berdasarkan hasil penelitian di lapangan, sebagian besar sebagian besar responden memiliki sikap positif terhadap BPJS dibandingkan dengan sikap negatif terhadap BPJS. Sikap positif ditunjukkan oleh sebagian besar menyatakan setuju dengan adanya program BPJS, Namun, responden merasakan pelaksanaan dilapangan masih banyak kekurangan terutama pada kualitas pelayanan yang diberikan kepada pasien sehingga menimbulkan sikap negatif terhadap BPJS.

Sikap yang positif bisa dijadikan dasar untuk mengambil keputusan yang tepat. Newcomb, salah seorang ahli psikologis sosial menyatakan bahwa sikap merupakan kesiapan atau kesediaan untuk bertindak, dan bukan merupakan pelaksanaan motif tertentu. Sebagai predisposisi perilaku maka sikap yang semakin tinggi maka semakin membuat dorongan yang kuat dalam dirinya. Jika sikap yang muncul adalah positif maka akan melahirkan perilaku positif. Salah satu sikap positif tersebut adalah dukungan atas program BPJS. Sikap positif pada peserta BPJS bisa didukung oleh umur yang mayoritas pada kategori usia 30-50 tahun.

\section{SIMPULAN}

Faktor perilaku konsumen yang terdiri dari informasi, dukungan keluarga dan sikap merupakan faktor yang menentukan jumlah kepesertaan BPJS di Kecamatan Glagah Kabupaten Lamongan. Sedangkan perilaku konsumen dari sisi pengetahuan tidak berhubungan nyata dengan jumlah kepesertaan BPJS di Kecamatan Glagah Kabupaten Lamongan.

\section{SARAN}

Berdasarkah hasil diatas rekomendasi untuk dapat meningkatkan jumlah kepesertaan BPJS di kecamatan Glagah adalah dengan memberikan informasi tentang BPJS kepada masyarakat dengan melibatkan keluarga agar terbentuk sikap yang mendukung program BPJS dan nantinya diharapkan berpengaruh kepada meningkatnya jumlah kepesertaan anggota BPJS di kecamatan Glagah kabupaten Lamongan. Contoh program nyata misalnya adalah memberikan reward tertentu bagi peserta BPJS yang berhasil mengajak anggota keluarganya menjadi anggota BPJS.

\section{DAFTAR PUSTAKA}

Hidayat, A., Fadmi, F. R., \& Juslan, J. (2019). Faktor-Faktor yang Berhubungan dengan Minat Masyarakat dalam Keikutsertaan Menjadi Peserta BPJS di Wilayah Kerja Puskesmas Mokoau Kota Kendari. MIRACLE Journal of Public Health, 2(1), 37-46. DOI: https://doi.org/10.36566/mjph/Vol2.Iss1.11

Hikmah, Z. N., Hidana, R., \& Chotimah, I. (2019). Faktor Pengetahuan, Dukungan Sosial dan Niat yang Berhubungan dengan Kepesertaan BPJS Kesehatan Mandiri Kepala Keluarga di Kelurahan Kedung Badak Kecamatan Tanah Sereal Kota Bogor Tahun 2018. PROMOTOR Jurnal Mahasiswa Kesehatan Masyarakat, 2(3), 240-249. DOI: http://dx.doi.org/10.32832/pro.v2i3.1943

Kurniawati, W., \& Rachmayanti, R. D. (2018). Identifikasi Penyebab Rendahnya Kepesertaan JKN pada Pekerja Sektor Informal di Kawasan Pedesaan. Jurnal Administrasi Kesehatan Indonesia, 6(1), 33-39. DOI: 10.20473/jaki.v6i1.2018.33-39 
Lestari, F. H., \& Djamaludin, M. D. (2017). Perception and Motivation of National Health Insurance Program Participation in Bogor. Journal of Consumer Sciences, 2(1), 39. https://doi.org/10.29244/jcs.2.1.39-50

Nadiyah, H., Subirman, S., \& Lusiana S, D. (2017). Faktor-Faktor yang Berhubungan dengan Kepesertaan Program JKN di Wilayah Kerja Puskesmas Remaja Kota Samarinda. Jurnal Kebijakan Kesehatan Indonesia, 6(2), 66-72. https://jurnal.ugm.ac.id/jkki/article/view/28931/17402

Nelisma, N., Afni, N., \& Rosnawati, R. (2019). Faktor-Faktor yang Berhubungan dengan Minat Masyarakat dalam Kepesertaan BPJS Kesehatan di Kelurahan Talise Valangguni. Jurnal Kolaboratif Sains, 1(1), 471-479. https://jurnal.unismuhpalu.ac.id/index.php/jom/article/view/828

Pangestika, V. F., Jati, S. P., \& Sriatmi, A. (2017). Faktor-Faktor yang Berhubungan dengan Kepesertaan Sektor Informal dalam BPJS Kesehatan Mandiri di Kelurahan Poncol, Kecamatan Pekalongan Timur, Kota Pekalongan. Jurnal Kesehatan Masyarakat, $5(3)$, 39-48. https://ejournal3.undip.ac.id/index.php/jkm/article/view/17165/16435

Plianbangchang, S. (2018). Universal Health Coverage (UHC). Journal of Health Research, 32(4), 322-324. https://doi.org/10.1108/JHR-05-2018-029

Purwaningsih, S. B. (2016). Faktor-Faktor yang Berhubungan dengan Keikutsertaan Masyarakat dalam Jaminan Kesehatan Nasional di Desa Tegalsari Kabupaten Ponorogo. Universitas Muhammadiyah Surakarta

Wardani, K. E., Purwaningsih, S. B., \& Purwanti, P. (2017). Keikutsertaan Kepala Keluarga Desa Tegalsari Ponorogo dalam Jaminan Kesehatan Nasional. Jurnal Manajemen Informasi Kesehatan Indonesia, 5(1), 85-91. DOI: 10.33560/.v5i1.154

World Health Organisation. (2017). WHO | Universal health coverage (UHC). WHO Fact Sheet. https://www.who.int/ 